\title{
Demarcated Opacities as Predictors of Progression of the Molar Incisor Hypomineralisation: a Pilot Study
}

\section{Demarkirani opaciteti kao prediktori progresije molarno- incizivne hipomineralizacije: pilot-studija}

\author{
${ }^{1}$ University of Sarajevo, Faculty of Dentistry with Clinics, Department of Pedodontics and Preventive Dentistry, Sarajevo, Bosnia and \\ Herzegovina \\ Katedra za dječju i preventivnu stomatologiju Stomatološkog fakulteta s klinikama Sveučilišta u Sarajevu, Bosna i Hercegovina \\ 2 University of Sarajevo, Medical Faculty, Pharmacology Department, Sarajevo, Bosnia and Herzegovina \\ Katedra za farmakologiju Medicinskog fakulteta Sveučilišta u Sarajevu, Bosna i Hercegovina
}

\section{Abstract}

Objectives: Demarcated opacities (DO) on teeth affected by Molar Incisor Hypomineralisation (MIH) were observed to investigate if parameters of DO existence and the number of teeth affected could be used to predict the progression of disease. Material and methods: In 2009, the MIH prevalence was $11.5 \%$ ( $n=51)$ among 446 subjects in Sarajevo, aged from 6 to 9 years. In subjects with MIH who gave consent for further participation $(n=25)$, the teeth with DO were observed after a 12 -month period. Results: our sample included 29 permanent incisors and 14 first permanent molars with DO. The number of teeth with light opacities was significantly higher than the number of teeth with dark opacities. Opacities were more numerous on surfaces which were not exposed to masticatory pressure. The size of tooth surface affected by DO occurrence ranged from $1.33 \%$ to $56.56 \%$. The number of affected teeth ranged from two to six. A strong positive correlation between MIH progression and dark colored opacities located on the occlusal/incisal surface of teeth was noted. Larger part of tooth surface was affected by hypomineralisation in the case of dark-colored opacities. The DO presence on incisors was more likely to be located on vestibular surfaces and on the first permanent molars on their occlusal surfaces. Conclusions: The color of DO occurrence was the best predictor for MIH progression both independently and in combination with the number of affected teeth. Location of DO occurrence was a good independent predictor for MIH progression. It is important to collect information about color and location of DO presence.
Received: April 17, 2020

Accepted: October 22, 2020

Address for correspondence Amra Arslanagić

University of Sarajevo

Faculty of Dentistry with Clinics

Department of Pedodontics and

Preventive Dentistry

Bolnička 4a, 71000 Sarajevo

Bosnia and Herzegovina

aarslanagic@sf.unsa.ba

Key words

Molar Incisor Hypomineralisations, MIH; Dental Enamel Hypoplasia; Tooth Discoloration; Disease Progression

\section{Introduction}

The question of an appropriate therapeutic approach to molar incisor teeth hypomineralisation (MIH) arose simultaneously with the research of their etiology and diagnostic criteria. As early as 2003, the studies of durability and adequacy of use of specific dental materials in the therapeutic treatment of affected teeth were published (1). The primary concern was clearly to identify the best therapeutic options for severely affected first permanent molars. The key question was if it is better to extract severely hypomineralised First Permanent Molars (FPM) early on or to attempt to preserve them.

Over the following years, more attention was given to treatment options for teeth affected by a mild form of MIH and esthetically focused treatment of $\mathrm{MIH}$-affected incisors. General treatment protocol was proposed $(2,3,4)$ which placed great importance on remineralization of initial lesions and desensitization of teeth, as well as prevention of dental caries and post eruptive enamel breakdown (PEB) (5).

One of the first studies that discovered the link between

\section{Uvod}

Usporedo s istraživanjem etiologije i kriterija za dijagnostiku molarno-incizivnih hipomineralizacija $(\mathrm{MIH})$ postavilo se pitanje odgovarajućega terapijskog pristupa. Već 2003. godine objavljena su istraživanja o dugotrajnosti i adekvatnosti primjene pojedinih stomatoloških materijala u terapiji zahvaćenih zuba (1). Naravno, najprije se nastojalo utvrditi najbolje opcije za tretman teže zahvaćenih prvih stalnih molara. Osnovni problem u pristupu pacijentima s teško hipomineraliziranim PSM-im bio je ustanoviti je li takve zube bolje pravodobno ekstrahirati ili ih pokušati sačuvati.

U godinama koje su slijedile više se pozornosti posvećivalo opcijama za tretman zuba s blagim oblicima hipomineralizacije te tretmanu inciziva iz estetskih razloga. Predložen je opći protokol $(2,3,4)$ u kojemu je istaknuto značenje remineralizacije inicijalnih lezija, desenzibilizacije zuba te prevencije karijesa i posteruptivnog puknuća cakline (PLC) (5).

Prvo istraživanje koje je pokazalo povezanost veličine i lokalizacije demarkiranih opaciteta s težinom kliničke slike da- 
the size and location of demarcated opacities (DO) and the severity of MIH in different age groups was conducted in 1987, but the primary focus of the study was to identify etiological factors involved in the onset of the defect (6).

Location of demarcated opacities was analyzed to establish the difference between the progressions of the defect on molars as opposed to its progression on incisors. Demarcated opacities on incisors were mostly located on vestibular surfaces. Low incidence of PEB occurrence in incisors was commonly attributed to limited exposure of incisors to masticatory forces. Demarcated opacities on incisors were thus primarily an esthetic concern for patients (7). There were documented cases, although very rare, of demarcated opacities located on the incisal edge where they were exposed to masticatory forces and thus progressed to PEB occurrence. On the other hand, the DO on molars could be located on surfaces which were not exposed to physical forces of mastication. A recent study that investigated hypomineralised FPM did not confirm that location of DO in the areas exposed to masticatory forces had any influence in aggravation to its breakdown (8).

Apart from its location, two other clinical characteristics of demarcated opacity - its color and size - are also important. Clinical studies documented the direct correlation between the color of demarcated opacities and the porousness and susceptibility of affected enamel to the development and progression of dental caries. Clinicians discovered in practice that darker opacities tended to be more severe which prompted histological studies to establish why that was the case. Yellow and yellow-brown-colored opacities were of full enamel thickness and were more prone to PEB development. With regards to histological evaluation, they were more porous and more susceptible to development and rapid progression of caries. On the other hand, creamy-yellow or white-yellowcolored opacities were inner hypomineralisations covered by a thin layer of fully mineralized enamel (9). It was necessary to study if the likelihood of preventing PEB was lower in cases where demarcated opacities were darker-colored. It was considered that the color of the opacity was an important predictor for the PEB occurrence (8).

MIH studies have not given proper attention to the size of demarcated opacities. The size was mostly used as an exclusion criterion for the opacities of less than $2 \mathrm{~mm}$ in diameter, as recommended by the Weerheijm criteria for the evaluation of MIH presence (10). Having assumed that the size of demarcated opacity was a good indicator of the severity of the defect as well as of the duration and severity of influence of the etiological factors, it was important to study this parameter.

In addition to the abovementioned three parameters related to the appearance of the affected tooth, the number of affected teeth, which was varying from one first permanent molar to, although it was very rare, all index teeth (4 permanent molars and 8 permanent incisors) being affected, was also of great clinical significance. It has been documented that the progressed stages of hypomineralisation (PEB occurrence, atypical fillings and extraction due to $\mathrm{MIH}$ progression) were more likely found in patients with a greater number of affected teeth, as well as that the likelihood of defects on incisors tira iz 1987. godine, ali primarni fokus toga istraživanja bila je etiološka pozadina nastanka poremećaja (6).

Lokacija demarkiranog opaciteta analizirana je, ali više zbog distinkcija između progresije bolesti na molarima i incizivima. Na incizivima se demarkirani opaciteti najčešce nalaze na labijalnoj površini. Smatra se da upravo zbog toga što na tu plohu ne djeluju mastikacijske sile, na njoj se rijetko dogada posteruptivno puknuće, ali ta promjena uglavnom estetski smeta pacijentima (7).

Dokumentirano je, iako rijetko, da demarkirani opacitet može biti na incizalnom rubu/plohi, izložen je pritom silama mastikacije i kao takav napreduje u PLC. S druge strane, DO na molarima može biti na plohama koje nisu izložene fiziološkim silama mastikacije. U novijim studijama istraživači nisu potvrdili da lociranost DO-a u područjima izvrgnutima silama utječe na mogućnost progresije u PLC-u (8).

Osim lokalizacije demarkiranoga opaciteta značajne su još dvije njegove kliničke karakteristike - boja i veličina.

U kliničkim opservacijama dokumentirano je da je boja demarkiranih opaciteta u izravnoj vezi sa stupnjem poroznosti cakline i njezine suspektnosti za razvitak i brzinu progresije karijesa.

$\mathrm{Na}$ osnovi histoloških studija objašnjeno je ono što je odavno uočeno u kliničkoj praksi - da su tamniji defekti klinički zahtjevniji. Pri promjeni žute ili žutosmeđe boje hipomineralizacija zahvaća cijelu debljinu cakline, a promjene su sklonije posteruptivnom puknuću. Histološki se odlikuju većom poroznošću cakline i suspektnije su kad je riječ o nastanku i brzini progresije karijesa. S druge strane, promjene u slučaju kremasto žute ili bijeložute boje histološki su uočene kao subpovršinske hipomineralizacije iznad kojih se nalazi tanki, dobro mineralizirani sloj cakline (9). Smatrali smo potrebnim ispitati umanjuje li tamnija boja demarkiranog opaciteta mogućnost da se prevenira posteruptivno puknuće cakline. Smatra se da je boja opaciteta značajan prediktor PLC-a (8).

Veličina demarkiranog opaciteta je $\mathrm{u}$ ispitivanju MIHa znatno zanemarena, uglavnom je spomenuta kao kriterij za isključivanje zuba iz analize ako je veličina demarkiranog opaciteta manja od $2 \mathrm{~mm}$, što je i preporučeno u Weerheijevim dijagnostičkim kriterijima MIH-a (10). Bazirano na pretpostavki da je veličina demarkiranog opaciteta dobar pokazatelj stupnja poremećaja, te u vezi s dužinom i jakošću djelovanja etiološkog čimbenika, smatrali smo bitnim ispitati i taj parametar.

Uz ta tri parametra koji opisuju izgled zahvaćenoga zuba, veliko kliničko značenje ima broj zahvaćenih zuba koji može varirati od jednoga prvog stalnog molara do, što je iznimno rijetko, svih indeksnih zuba (4 prva stalna molara i 8 stalnih inciziva). Dokumentirano je da kod pacijenata $s$ većim brojem zahvaćenih zuba češće uočavamo ozbiljnije defekte (posteruptivno puknuće, netipični ispuni i ekstrahirani zubi kao posljedica MIH-a), te da mogućnost defekata na incizivima raste $s$ povećanjem broja zahvaćenih molara (11).

Smatra se da, što su etiološki čimbenik i/ili čimbenici jači i/ili dulje djeluju, to je broj zahvaćenih zuba veći i teži je stupanj hipomineralizacije. Istraživanja su pokazala da postoji korelacija između broja aficiranih zuba i oblika hipomineralizacije te razdoblja djelovanja etiološkog čimbenika. Broj 
increased in parallel with the number of affected molars (11). The severity of hypomineralisation was believed to increase with the strenght and durability of etiological factor(s) influence. The number of affected teeth depended on the stage of enamel formation (prenatal, perinaltal or postnatal) in which the noxious factor occurred - latter occurrence resulted in more affected teeth (12). It was worth studying the correlation between the progression of demarcated opacity of one tooth and the total number of affected teeth of a patient.

Clinical forms of MIH presence were demarcated opacity (DO), post eruptive enamel breakdown (PEB), atypical filling (AF) and extracted tooth due to MIH progression (EX). Recently it was recommended to register atypical caries as an additional category (13). The distribution of clinical forms of MIH (DO; PEB; AF; EX) varied in different population groups. It was very important to establish the prevalence of teeth with DO presence which were the least severe form of MIH occurrence. DO occurrence was registered on 45.8\% (Finland), 74.0\% (Greece) and 84.5\% (Germany) index teeth in studies in which the subjects were older than 9 years $(11,14,15)$. A study conducted in Bosnia and Herzegovina in 2004 established that MIH occurrence affected $12.3 \%$ of 12 -year-olds, and $47 \%$ of examineed index teeth were registered with defining clinical features of MIH. DO occurrence was noted on $25.0 \%$, PEB on $8.6 \%$ and $\mathrm{AF}$ on $4.6 \%$ of examined index teeth, respectively, while $8.8 \%$ index teeth were extracted due to MIH progression (15). This distribution among $\mathrm{BH} 12$-year-olds implied that half of the teeth afected by DO did not progress to severe stages of $\mathrm{MIH}$ apperance (PEB, AF, EX), in 5 to 6 years post eruption (16).

The questions were as follows: What was behind the progression from DO existence to PEB occurrence, and why demarcated opacities did not change on some teeth? This study aimed to investigate if, and to what extent, color, size and location of DO presence were impacting its progression as well as to determine the connection between the DO progression and the number of teeth affected in individual subjects.

\section{Material and methods}

\section{Primary sample included}

446 participants aged from 6 to 9 years were examined in Sarajevo in 2009. The prevalence of MIH presence in this sample was $11.5 \%(\mathrm{n}=51)$. Only the subjects with MIH presence, where parental consent for further participation in one year period was obtained $(n=25)$, were included in this study.

The research method was a longitudinal, analytical study and the sample was constituted from first permanent molars and incisors with demarcated opacities of the above mentioned study participants, where their baseline examination was performed in 2009. Each tooth was photographed with intra-oral camera (SONY DCC F717 Cyber-shot). The features of DOs for each tooth were registered as follows: color (light/ dark), location (tooth surface exposed/ not exposed to masticatory forces), size of demarcated opacity and number of teeth affected. The photographs served to calculate the size of tooth surface affected by demarcated opacities. The MAT$\mathrm{LAB}^{\circ}$ computer program was used to create an application to zahvaćenih zuba, molara i inciziva, veći je ako je noksa počela kasnije djelovati (prenatalno, perinatalno ili postnatalno), a najveći broj zahvaćenih zuba imali su ispitanici kod kojih su postojali kombinirani perinatalni i postnatalni problemi (12). Zanimljivo je ispitati vezu progresije demarkiranog opaciteta na jednom zubu s ukupnim brojem zahvaćenih zuba kod istog pacijenta.

Klinički oblici MIH-a su demarkirani opacitet (DO), posteruptivno puknuće cakline (PLC), netipični ispun (AI) i zubi ekstrahirani zbog progresije (EX). Nedavno je predložena i dodatna kategorija - netipični karijes (13).

Zanimljivo je pratiti distribuciju kliničkih pojavnih oblika MIH-a (DO; PLC; AI; EX) u raznim istraživanim populacijama.

Registracija zuba s DO-om kao najblažim oblikom MIHa vrlo je važna. Blagi oblik uočen je kod 45,8 \% (Finska), 74 \% (Grčka) i 84,5 \% (Njemačka) indeksnih zuba u populacijama pregledanih ispitanika starijih od 9 godina $(11,14,15)$. U studiji iz Bosne i Hercegovine (2004. god) u kojoj je utvrđena prevalencija $\mathrm{MIH}-\mathrm{a}$ od $12,3 \%$ kod dvanaestogodišnjaka, istaknuto je da je kod ispitanika $47 \%$ indeksnih zuba bilo zahvaćeno promjenama. DO je zabilježen na $25 \%$ indeksnih zuba, PLC na 8,6 \%, AI na 4,6 \% a, 8,8 \% indeksnih zuba ekstrahirano je zbog posljedica progresije MIH-a (15). Distribucija pojavnih oblika hipomineralizacija upućuje na zaključak da od svih zuba s demarkiranim opacitetom, polovina ne prelazi u teže kliničke oblike (PLC, AI, EX), odnosno ne mijenja se 5 do 6 godina poslije nicanja (16).

Nametnulo se pitanje što je to odgovorno za posteruptivno puknuće cakline, odnosno zašto ga na pojedinim zubima nema. $U$ ovom istraživanju nastojalo se odgovoriti i na pitanje u kojoj su mjeri boja, veličina i lokacija DO-a odgovorne za progresiju bolesti te istražiti povezanost napredovanja bolesti s ukupnim brojem zahvaćenih zuba kod istog pacijenta.

\section{Uzorak i postupci}

\section{Primarni uzorak}

Primarni uzorak činilo je 446 ispitanika u dobi od 6 do 9 godina, a pregledani su u Sarajevu 2009. godine. Utvrdena je prevalencija MIH-a od 11,5\%, $(\mathrm{n}=51)$. Daljnjim istraživanjem obuhvaćeni su ispitanici s potvrđenom dijagnozom MIH-a čiji su se roditelji složili s njihovim jednogodišnjim sudjelovanjem u studiji $(\mathrm{n}=25)$.

Uzorci longitudinalne analitičke studije bili su prvi stalni molari i stalni incizivi na kojima su uočeni demarkirani opaciteti u navedenoj ispitivanoj skupini. Prvi pregled obavljen je 2009. godine. Zubi su fotografirani intraoralnom kamerom (SONY DCC F717 Cyber-shot).

Za svaki demarkirani opacitet korišteni su sljedeći parametri: boja (svijetla/ tamna); lokacija (ne izložen/izložen silama žvakanja), veličina demarkiranog opaciteta i broj zuba zahvaćenih hipomineralizacijama.

Fotografije su korištene za izračun površine zuba zahvaćene demarkiranim opacitetom. U kompjutorskom programu 


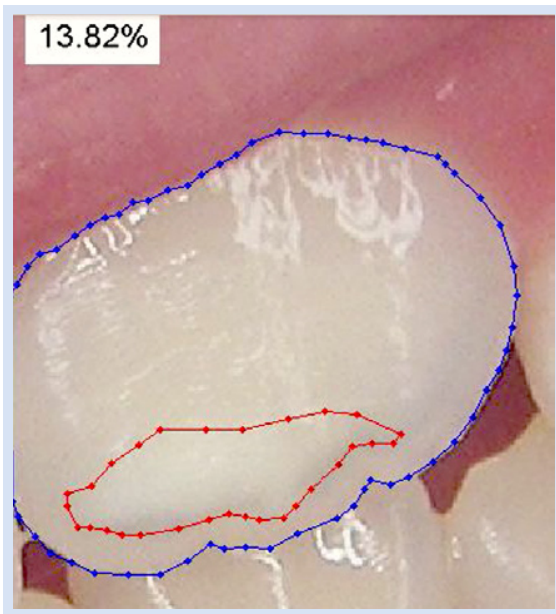

Figure 1 Calculation of tooth surface affected by demarcated opacities using MATLAB ${ }^{\circledR}$ computer program

Slika 1. Proračun površine zuba zahvaćenih razgraničenim opalescencijama izrađen pomoću računalnog programa MATLAB ${ }^{\circledR}$

calculate the tooth surface affected by demarcated opacities expressed as a percentage of the total tooth surface (vestibular/oral or occlusal surface) (Image 1.). The teeth with decay, filling or developmental defects of other etiology $(n=3)$ were excluded from the study sample.

The follow- up examination was conducted in 2010 . Each tooth was photographed and the presence of progression from demarcated opacity to post-eruptive enamel breakdown, an atypical filling or teeth extracted due to MIH were noted.

Further methods of statistical analysis were used: description, inferential analysis, distribution, correlation, and binar logistic regression analysis. The Statistical Package for Social Science, version 15.0 (SPSS Inc., Chicago, IL, SAD) was used for the purpose of these statistical testings.

\section{Results}

The research sample consisted of 43 teeth with demarcated opacities in total, with 29 permanent incisors and 14 first permanent molars included. The most prevalent teeth in the sample were upper first permanent incisors $(\mathrm{n}=22)$, followed by lower first permanent molars ( $\mathrm{n}=8)$, upper first permanent molars $(n=6)$, and upper second permanent incisors $(n=5)$. Also, one mandibular first permanent incisor and one second permanent incisor were included.

The number of teeth with light-colored opacities $(n=35)$ was higher than the number of teeth with dark-colored opacities $(n=8)$. Opacities were more numerous on surfaces which were not related to those exposed to masticatory pressure $(\mathrm{n}=32$ compared to $\mathrm{n}=11)$. Out of 32 surfaces which were not exposed to masticatory pressure, 5 were located on first permanent molars and 27 on incisors. Demarcated opacities located on surfaces exposed to masticatory pressure were registered on 9 first permanent molars and 2 permanent incisors.

The size of tooth surface affected by demarcated opacities, expressed as percentage of total tooth surface, ranged from $1.33 \%$ to $56.56 \%$. The number of affected teeth ranged from two to six. The observed parameters of demarcated opacity and its progression after one-year period are presented in Table 1.

The number of dark opacities was small: only 5, out of which the progression was noted in 3 cases. A smaller num-
MATLAB $^{\circledast}$ otvorena je aplikacija za izračunavanje postotka vrijednosti površine zahvaćene demarkiranim opacitetom u odnosu prema ukupnoj površini vestibularne/oralne ili okluzalne/incizalne plohe (slika 1.). Zubi s karijesom, ispunom ili razvojnim defektom druge etiologije $(\mathrm{n}=3)$ bili su isključeni.

Završni pregled bio je 2010 godine. Zubi su ponovno fotografirani te su evidentirani progresija demarkiranog opaciteta u posteruptivno puknuće cakline, netipični ispun ili ekstrakcija zuba.

Korištene su metode statističke analize - deskripcija, inferencijalna analiza, ispitivanje normalnosti distribucije podataka, korelacija i binarna logistička regresijska analiza.

$\mathrm{Za}$ obradu podataka i statističku analizu korišten je program SPSS 15.0 (SPSS,Inc. Chicago, II, SAD).

\section{Rezultati}

Uzorci su bila 43 zuba s demarkiranim opacitetima - 29 stalnih inciziva i 14 prvih stalnih molara. Najzastupljeniji zubi bili su prvi stalni incizivi u gornjoj čeljusti $(\mathrm{n}=22)$, prvi stalni molari u donjoj čeljusti $(\mathrm{n}=8)$, prvi stalni molari u gornjoj čeljusti $(n=6)$, zatim drugi stalni incizivi u gornjoj čeljusti $(n=5)$ te po jedan prvi i drugi stalni inciziv u donjoj čeljusti.

Broj zuba sa svijetlim demarkiranim opacitetima $(\mathrm{n}=35)$ bio je znatno veći negoli s tamnima $(\mathrm{n}=8)$. Brojniji su bili demarkirani opaciteti locirani na glatkim plohama koje ne podnose pritisak žvačnih sila negoli oni na površinama izloženim pritisku (32 prema 11). Od 32 površine s DO-om koje nisu bile izložene žvačnom pritisku, 5 je bilo na molarima, a 27 na incizivima. Demarkirani opaciteti na plohama izvrgnutim silama uočeni su na 9 prvih stalnih molara i 2 stalna inciziva.

U postotku se zahvaćenost zubnih površina demarkiranim opacitetom kretala se od 1,33\% do 56,56\%. Broj zahvaćenih zuba kod promatranih ispitanika kretao se od 1 do 6 .

Distribucija zuba prema parametrima demarkiranog opaciteta u odnosu prema progresiji nakon jedne godine prikazana je u tablici 1.

Od malog broja zuba s tamnim demarkiranim opacitetom, $(\mathrm{n}=5)$, na njih tri je zabilježena progresija. Veći broj 
Table 1 Distribution of observed parameters in affected teeth in the sample in accordance with progression after one year.

Tablica 1. Raspodjela opaženih parametara na zahvaćenim zubima u skladu s napredovanjem nakon jedne godine

Initial appearance of demarcated opacities

Color of demarcated opacity

Location of demarcated opacity

Number of

MIH-affected teeth

Size of affected surface

\section{Progression after one year \\ Yes \\ No \\ Total teeth affected $(\mathrm{N}) \bullet$}

33

\begin{tabular}{|l|c|c|c|}
\hline Light & 2 & 33 & 35 \\
\hline Dark & 5 & 3 & 83 \\
\hline Number of teeth & 7 & 36 & 32 \\
\hline Vestibular/oral & 0 & 32 & 11 \\
\hline Occlusal/Incisal & 7 & 4 & 43 \\
\hline Number of teeth & 7 & 36 & 11 \\
\hline $1-5 \%$ & 1 & 10 & 12 \\
\hline $5-10 \%$ & 1 & 11 & 7 \\
\hline $10-15 \%$ & 2 & 5 & 7 \\
\hline $15-20 \%$ & 1 & 6 & 6 \\
\hline$>20 \%$ & 2 & 4 & 43 \\
\hline Number of teeth & 7 & 36 & 9 \\
\hline 2 & 1 & 0 & 10 \\
\hline 3 & 2 & 7 & 17 \\
\hline 4 & 4 & 6 & 6 \\
\hline 5 & 0 & 17 & 43 \\
\hline 6 & 0 & 6 & 36 \\
\hline Number of teeth & 7 & & \\
\hline
\end{tabular}

Table 2 Correlations for predictive regression model

Tablica 2. Korelacije za prediktivni regresijski model

\begin{tabular}{|c|c|c|c|c|c|}
\hline \multicolumn{2}{|c|}{ Correlations of observed parameters } & \multirow{2}{*}{$\begin{array}{c}\text { Disease progression } \\
\qquad-0.366^{*} \\
\end{array}$} & \multirow{2}{*}{$\begin{array}{c}\text { Light/ dark color of } \\
\text { opacity } \\
-0.305^{*} \\
\end{array}$} & \multirow{2}{*}{ 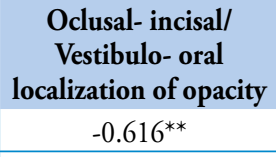 } & \multirow{2}{*}{$\begin{array}{c}\% \text { of toot surface } \\
\text { affected with opacity } \\
-0.176\end{array}$} \\
\hline Permanent first molar/ & Pearson correlation & & & & \\
\hline incisor & Significance & 0.016 & 0.046 & 0.000 & 0.260 \\
\hline \multirow{2}{*}{$\begin{array}{l}\text { Light/ dark color of } \\
\text { opacity }\end{array}$} & Pearson correlation & 0.599 ** & 1 & $0.405^{* *}$ & $0.468^{* *}$ \\
\hline & Significance & 0.000 & & 0.007 & 0.002 \\
\hline \multirow{2}{*}{$\begin{array}{l}\text { Oclusal- incisal/ } \\
\text { Vestibulo- oral } \\
\text { localization of opacity }\end{array}$} & Pearson correlation & $0.752^{* *}$ & $0.405^{* *}$ & 1 & 0.110 \\
\hline & Significance & 0.000 & 0.007 & & 0.484 \\
\hline \multirow{2}{*}{$\begin{array}{l}\text { Number of teeth } \\
\text { affected }\end{array}$} & Pearson correlation & $-0.420^{* *}$ & -0.078 & $-0.339^{*}$ & 0.086 \\
\hline & Significance & 0.005 & 0.621 & 0.026 & 0.585 \\
\hline
\end{tabular}

\begin{tabular}{|c|c|c|c|c|c|c|c|c|}
\hline \multirow[t]{2}{*}{ Variables } & B & S.E. & Walid & df & Sig. & $\operatorname{Exp}(B)$ & \multicolumn{2}{|c|}{ 95,0\% C.I. for $\operatorname{EXP}(B)$} \\
\hline & & & & & & & lower & higher \\
\hline Dark color of opacity & -5.104 & 2.007 & 6.469 & 1 & 0.011 & 0.006 & 0.000 & 0.310 \\
\hline Number of affected teeth & -2.159 & 1.065 & 4.111 & 1 & 0.043 & 0.115 & 0.014 & 0.931 \\
\hline Constant & 10.290 & 5.002 & 4.232 & 1 & 0.040 & 29444.279 & & \\
\hline
\end{tabular}

ber of teeth investigated were those with demarcated opacity located on surfaces which were exposed to masticatory pressure (occlusal/incisal), and the progression was observed only on those teeth.

A binary logistic regression analysis was used for prediction of disease progression from DO to PEB, AF or EX. The progression of demarcated opacity was observed as a dependent variable. Five potential predictive variables were con- zuba uključenih u istraživanje bio je s demarkiranim opacitetom na plohama neizloženim silama tijekom žvakanja (vestibularno/oralne plohe). Progresija bolesti dijagnosticirana je isključivo na zubima na kojima su demarkirani opaciteti bili na plohama izloženim pritisku (okluzalno/incizalnim).

Za predikciju nastanka posteruptivnog puknuća cakline korištena je binarna logistička regresijska analiza. Progresija bolesti promatrana je kao zavisna (ishodišna) varijabla. Raz- 
sidered: tooth (first permanent molar or permanent incisor), color of demarcated opacity (dark or light), the location of demarcated opacity (vestibular/ oral or occlusal/incisal), the size of demarcated opacity (expressed as a percentage of the total tooth surface) and the number of teeth affected.

To identify the relationship between predictors and dependent variable, a correlation test was used in order to investigate the overall possibility of their use as predictors for post eruptive enamel breakdown (Table 2).

Moderate to severe correlation within the predictors was noted between independent variables such as: the type of tooth (first permanent molar/permanent incisor), the color of the opacity (light/ dark), the location and the number of affected teeth; and one dependent variable such as the progression of disease. The correlation between the progression of the disease and the percentage of tooth surfaces affected, as independent variable, was not found.

An Enter model of Binary Logistic Regression was used for the regression analysis to confirm the adequate use of the model: Omnibus test of model coefficients had a significant value (Chi -square test was 21.967, $\mathrm{p}<0.001$, with 2 degrees of freedom). The Hosmer and Lemesh test showed a non-significant value of $p>0.05$. The Cox \& Snell R Square test and the Nagelkerke R Square test showed that this model had explained $40-67 \%$ of variance of the results in the sample.

According to the Enter Logistic Regression model two variables provided an adequate explanation of the prediction of demarcated opacity progression. Those were dark color of DO and a total number of teeth affected in study participants. (Table 2)

The location of demarcated opacity was the independent variable that did not meet criteria. Disease progression appeared only on teeth with $\mathrm{DO}$, and was localized on surfaces exposed to masticatory forces, and therefore this parameter was not analyzed by means of logistic regression.

\section{Discussion}

The first study focused on clinical characteristics of demarcated opacities was the study conducted by Koch et al. in 1987 (6). This was also the first study conducted on several age cohorts within the same population, on representative sample of participants. The methodology of this study was based on division of tooth surface in 4 areas. The occlusal area was one, while remaining three areas were incisal, middle and gingival area of vestibular surface. The following two clinical parameters of hypomineralised teeth were observed: color (white, yellow, brown) and appearance of enamel surface (rough, abraded, disintegrated, covered with atypical filling). Teeth were registered as hypomineralised if the changes (color or surface) were present on more than $1 / 3$ of a tooth area. Although the importance of color and size of a hypomineralisation was recognized in this study, the distribution of opacities according to color and location was not presented.

Histomorphological and biochemical characteristics of hypomineralised enamel were investigated on a sample of 73 hypomineralised teeth (9). It was discovered that dark-colored opacity was a result of hypomineralisation in the entire matrano je pet potencijalnih predikacijskih varijabli: vrsta promatranog zuba (prvi stalni molar ili stalni inciziv), boja demarkiranog opaciteta (svijetla ili tamna), lokacija demarkiranog opaciteta (vestibularno/oralna ili okluzalno/incizalna), veličina, $\mathrm{tj}$. postotak površine zuba $s$ demarkiranim opacitetom i ukupan broj hipomineraliziranih zuba.

Povezanost prediktora i zavisne varijable analizirala se testiranjem povezanosti kako bi se ispitala mogućnost njihove upotrebe kao prediktora posteruptivnog puknuća cakline (tablica 2.).

Uočena je umjerena do snažna interkorelacija prediktora: prvi stalni molar/stalni inziciv, boja tamna/svijetla, lokacija, broj zahvaćenih zuba i zavisne varijable: progresija bolesti. Nije ustanovljena interkorelacija između progresije bolesti i varijable: postotak zahvaćene površine.

Za regresijsku analizu korišten je model binarne logističke regresijske analize s obilježjima koja objašnjavaju adekvatnost modela: omnibus test (Hi-kvadrat test 21,967, p < 0,001, 2 stupnja slobode) Hosmer-Lemeshov test s nesignifikantnom vrijednošću od $\mathrm{p}>0,05$, a vrijednosti Cox i SnellR. Squarova i Nagelkerke-R. Squarova testova pokazuju da taj model objašnjava od 40 do $67 \%$ varijance uzorka.

Prema analizi modela, dvije varijable koje odgovarajuće objašnjavaju predikciju progresije bolesti iz inicijalnog oblika (demarkiranog opaciteta) jesu boja zuba (tamna) i ukupan broj zuba s inicijalnim oblikom MIH-a (demarkirani opacitet) (tablica 2.).

Varijabla koja je uvrštena u model, ali nije zadovoljila adekvatnost regresijske analize, jest lokacija inicijalne promjene (demarkiranog opaciteta). Kontingencijski nalaz pokazuje da ne postoji ni jedan slučaj progresije bolesti kada je inicijalna promjena (demarkirani opacitet) na vestibularnoj ili oralnoj strani, pa taj parametar nije razmatran u regresijskoj analizi.

\section{Rasprava}

Najraniji pokušaj analiziranja kliničkih obilježja demarkiranih opaciteta jest epidemiološka opservacijska studija Kocha i suradnika iz 1987. godine (6). To je bila prva studija u kojoj je analizirana dobna kohorta $u$ istoj populaciji na reprezentativnom uzorku ispitanika. Metodologija toga istraživanja temeljila se na podjeli zuba na jedinice. Okluzalna površina promatrana je kao jedna jedinica, a glatke plohe bile su podijeljene na tri jedinice (incizalnu, srednju i gingivalnu). Analizirane su dvije karakteristike - boja zuba (bijela, žuta, smeđa) i promjene na površini cakline (hrapava, abradirana, dezintegrirana, netipični ispun). Zub se smatrao hipomineraliziranim samo ako je promjena u boji ili strukturi zahvaćala više od jedne trećine zubne jedinice. $U$ studiji je prepoznato značenje površine zuba zahvaćenog promjenom, zatim boje demarkiranog opaciteta, ali distribucija promjena u boji nije prikazana, kao ni distribucija najčešće zahvaćenih površina zuba.

Histomorfološka i biokemijska obilježja hipomineralizirane cakline na uzorku od 73 hipomineralizirana zuba (9) pokazuju da je u slučaju tamnijih opaciteta hipomineralizaci- 
thickness of the enamel, while light-colored opacity was a result of hypomineralisation in subsurface area of the enamel. In booth kind of opacities, dark and light-colored ones, the surface of the enamel was glossy and solid. This discovery explained why dark-colored opacities were more prone to post-eruptive enamel breakdown. The possibility that chalky enamel is not a consequence of previously investigated etiological factors, but rather of a primary causal event during amelogenesis, has been under consideration. A biochemical analysis revealed the presence of extracellular serum albumin in the hypomineralised enamel. Recent findings indicate that blood-derived albumin infiltrates the immature enamel and directly blocks its mineralization. "The molecular timestamping" approach revealed traces of fetal albumin in intact opacities, signifying that localized exposure of the enamel to serum albumin during amelogenesis, rather than systemic injury to ameloblast, constitutes the crux of MIH pathogenesis (17).

In our sample of tooth observed, light-colored opacities were dominant $(n=35)$ over dark-colored ones $(n=8)$. There was a possibility that dark-colored opacities progressed in post-eruptive enamel breakdown during the examination. The color of the hipomineralised enamel, as assessed visually or by laser fluorescence, might be used clinically to reflect the severity of the defect. This seemed to play an important role on the PEB occurrence and should be considered as a potential predictor $(8,18)$. A strong positive correlation between the MIH progression and dark color of demarcated opacities was confirmed in our investigation.

The size of demarcated opacities was registered differently in available published studies. Some authors from Finland thus divided opacities in 3 categories, based on a size less than $2 \mathrm{~mm}, 2$ to $4 \mathrm{~mm}$ and larger than $4 \mathrm{~mm}$ (14). The actual measured size of demarcated opacities expressed in millimeters was reported in several studies $(19,14)$. Most of the MIH surveys registered only those opacities that were larger than 2 $\mathrm{mm}(9,14,19,20)$, with the recommended usage of graduated periodontal probe (20). European Academy of Pediatric Dentistry (EAPD) later recommended registration of opacities larger than $1 \mathrm{~mm}(21)$. In a recently developed MIH index, lesion extension was registered in 3 stages, such as: less than one-third of the tooth affected, at least one-third but less than two-thirds of the tooth affected, and at least two-thirds of the tooth affected (13). In our study, the size of demarcated opacities was expressed as a percentage of tooth surface affected, and it was ranged from $1.33 \%$ to $56.56 \%$. A correlation between size of demarcated opacity and MIH progression was not detected in our research.

Demarcated opacities were located mostly on occlusal surfaces, followed by buccal ones, while lingual surfaces were rarely affected (14). The EAPD defined that demarcated opacity could be located on occlusal and buccal surfaces but a need for separate registration according to location was not mentioned (21). In our research, demarcated opacities were registered on all tooth surfaces, and only one was located on the lingual surface of upper permanent first molar.

In our study, the number of teeth with demarcated opacities located on surfaces not exposed to masticatory forces was higher than those on occlusal/ incisal ones (32 vs. 11), but ja prisutna u cijeloj debljini cakline, za razliku od svjetlijih u kojima je hipomineralizirano područje subpovršinsko. U oba slučaja hipomineralizirano područje prekriveno je sjajnom i čvrstom površinskom caklinom. Time je objašnjeno zašto su tamniji opaciteti skloniji posteruptivnom puknuću cakline, što je uočeno i u praksi.

Trenutačno se razmatra je li moguće da je razmekšana caklina prouzročena primarnim uzročnim događajima tijekom amelogeneze, te da nije posljedica razmatranih etioloških čimbenika. Biokemijskim analizama otkriven je ekstracelularni serumski albumin u hipomineraliziranoj caklini. U novijim istraživanjima autori ističu da albumin podrijetlom iz krvi infiltrira nezrelu caklinu i izravno blokira njezinu mineralizaciju. Tragovi fetalnog albumina u intaktnim opacitetima, otkriveni tijekom molekularnog mapiranja vremena, upućuju na to da je lokalizirano izlaganje cakline serumskim albuminima tijekom amelogeneze osnova patogeneze $\mathrm{MIH}$-a prije negoli sistemsko oštećenje ameloblasta (17).

U našem uzorku promatran je veći broj zuba s demarkiranim opacitetom svijetle boje $(\mathrm{n}=35)$ u odnosu prema tamnima $(\mathrm{n}=8)$. To se može tumačiti, a imajući na umu navedena istraživanja, kao mogućnost da su opaciteti tamne boje već progredirali u PLC u trenutku pregleda. Boja hipomineralizirane cakline, procijenjena vizualno ili primjenom laserske fluorescencije, može se koristiti u kliničkoj procjeni težine defekta. Boja DO-a važna je u nastanku PL-a i treba se uzeti u obzir kao potencijalni prediktor progresije $(8,18)$. U našem istraživanju utvrđena je korelacija tamne boje demarkiranog opaciteta i progresije bolesti.

Veličina demarkiranog opaciteta u dostupnim istraživanjima obrađena je na različite načine. $U$ studiji finskih istraživača svrstan je u tri kategorije (manji od $2 \mathrm{~mm}$, od 2 do 4 $\mathrm{mm}$ i veći od $4 \mathrm{~mm}$ ) (14). Stvarna veličina demarkiranih opaciteta dosad je zabilježena u nekoliko studija, a na osnovi veličine izražene u milimetrima $(19,14)$.

Kao kriterij za demarkirane opacitete u većini istraživanja navodi se da se promjene uočavaju ako su veće od $2 \mathrm{~mm}$ $(9,14,19,20)$, uz preporuku da se upotrebljava milimetarski graduirana parodontna sonda (20). Europska akademija za pedijatrijsku stomatologiju (EAPD) preporučuje da se demarkirani opaciteti bilježe ako su veći od $1 \mathrm{~mm}$ (21).

$\mathrm{U}$ nedavno predloženom indeksu $\mathrm{MIH}-\mathrm{a}$, veličina promjene sadržava 3 kategorije - zahvaćeno je manje od jedne trećine zuba, zahvaćeno je više od jedne trećine, ali manje od dvije trećine zuba i treća je kategorija kada su zahvaćene minimalno dvije trećine zuba (13).

$\mathrm{U}$ našem istraživanju zabilježena je veličina promjene na temelju vrijednosti postotne zahvaćenosti zubne površine hipomineralizacijom. Raspon veličina demarkiranih opaciteta na ispitivanim zubima bio je velik - od 1,33\% do 56,56 \%. Korelacija između postotnih vrijednosti demarkiranih opaciteta i progresije bolesti nije ustanovljena.

Demarkirani opaciteti najčešće se uočavaju na okluzalnim i bukalnim površinama zuba, a rijetko na lingvalnima (14). Europska akademija za pedijatrijsku stomatologiju (EAPD) navodi da se demarkirani opaciteti nalaze na okluzalnim i bukalnim površinama zuba, bez napomene da li se kao takvi i registriraju (21). U našem istraživanju evidentira- 
$2 / 3$ of our sample were incisors. The post-eruptive enamel breakdown was rarely seen on incisors $(1,10)$. Examination in earlier age of patients should enable registration of hypomineralisations in initial stage (demarcated opacity). However, in some of our study participants, the post-eruptive enamel breakdown was registered on first permanent molars that were not fully erupted. It seemed that in our sample population the PEB presence could happen even before a tooth was exposed to masticatory forces. A possible explanation for that was that the post-eruptive maturation of the permanent tooth enamel was compromised due to inadequate oral hygiene and high caries rates in primary dentitions of our examinees. The absence of well mineralized surface above the hypomineralisation area was making tooth less resistant. The post eruptive breakdown (PEB) in our sample $(\mathrm{n}=7)$ was registered after one year, mainly on first permanent molars with an exception of one permanent incisor in which demarcated opacity was located on the incisal edge. The location of demarcated opacity on occlusal/incisal surfaces was proven to be a reliable independent predictive factor.

The importance of the number of teeth affected by hypomineralisation and the severity of molar incisor hypomineralisation were well documented (22-24). A chance of permanent incisor affection by hypomineralisation increased when larger numbers of first permanent molars were affected $(24,25) .70 \%$ of children with progressive stages of hypomineralisation on first permanent molars had demarcated opacities on permanent incisors $(22,23)$. The severity of $\mathrm{MIH}$ presence was associated with the number of teeth with $\mathrm{MIH}$ existence, meaning that participants with opacities only had a lower mean number of teeth involved compared to those with severe lesions (i.e. PEB, AF, and EX) cases of MIH progression (13). Our research findings confirmed a negative correlation between $\mathrm{MIH}$ progression and the number of affected teeth. Progression was noted only on the teeth of subjects that had less than four teeth affected. This could not be interpreted in a way that smaller number of teeth affected meant a higher risk of progression, since it was opposite to findings in other researche. In our sample, first permanent molars with demarcated opacities, which were followed for one year, were mostly present in subjects with post-eruptive enamel breakdown or atypical filling on remaining first permanent molars. Also, permanent incisors with demarcated opacities observed were present in subjects with first permanent molars on which progressive stages were already present.

The location of demarcated opacities was not analyzed in regression model since all demarcated opacities that progressed after one year were located on surfaces exposed to masticatory forces. The abovementioned stressed the importance of location together with a high correlation of DO progression and DO location on occlusal/ incisal surfaces, which was an important finding in our research.

The size of tooth surface affected by demarcated opacities (expressed as a percentage) did not enter in final prediction model, which could be due to small number of teeth observed.

Limitations of our study were that age of observed population (from 6 to 9 years) did not allow registration of initial ni su demarkirani opaciteti na bilo kojoj površini zuba. Demarkirani opaciteti i na lingvalnoj plohi uočeni su samo kod jednog ispitanika i to na gornjim PSM-ima.

U našem istraživanju je broj demarkiranih opaciteta na glatkim plohama bio znatno veći negoli na okluzalno/incizalnima (32/11), ali treba imati na umu da su incizivi, na kojima su demarkirani opaciteti najčešće locirani vestibularno, činili dvije trećine uzorka.

Posteruptivno puknuće cakline rijetko je na incizivima $(1,10)$. Upravo su pregledi ispitanika u ranijoj dobi i njihovo praćenje trebali omogućiti da se uoči hipomineralizacija u inicijalnom stadiju (DO), ali se pokazalo da se na pojedinim prvim stalnim molarima u erupciji pojavio PLC, dakle prije nego što su zubi bili izloženi žvačnim silama.

Moguće objašnjenje bilo bi da je kod naših ispitanika, zbog neodgovarajuće oralne higijene i čestih aktivnih karioznih lezija u mliječnoj denticiji, kompromitirana posteruptivna maturacija površinske cakline. Zato nema dobro mineraliziranog sloja cakline iznad hipomineralizirane zone, što smanjuje otpornost zuba.

U našem uzorku je posteruptivno puknuće cakline nakon godinu dana $(\mathrm{n}=7)$ uočeno uglavnom na prvim stalnim molarima te na samo jednom incizivu na kojemu je demarkirani opacitet, bijele boje bio na incizalnom rubu. Utvrđena je visoka povezanost progresije i zuba na kojima je demarkirani opacitet bio na površini izloženoj većem pritisku (okluzalne i incizalne površine).

$\mathrm{U}$ mnogim istraživanjima ističe se da je broj zahvaćenih zuba kod ispitanika u kontekstu težine kliničke slike (22 24). Što je više zuba zahvaćeno PSM-om, to je veća mogućnost hipomineralizacije na incizivima $(24,25)$. Dodajmo da $70 \%$ djece s progresivnim stadijima na PSM-u ima demarkirane opacitete na incizivima $(22,23)$.

Broj zahvaćenih zuba kod ispitanika s MIH-om teoretski se kreće od 1 do 12 . Dok su situacije $s$ jednim zahvaćenim molarom česte, $u$ literaturi nije naveden slučaj s maksimalnim brojem zahvaćenih zuba.

Težina kliničke slike MIH-a povezana je s brojem zuba zahvacenih hipomineralizacijom. Ispitanici kod kojih su uočeni samo demarkirani opaciteti imali su manje zahvaćenih zuba u usporedbi s onima koji su imali progresivne oblike (PLC, AI, EX) (13).

U našem istraživanju uočena je negativna korelacija između broja zahvaćenih zuba i progresije bolesti. Progresija na pojedinim praćenim zubima dogodila se samo kod ispitanika s manje od četiri zahvaćena zuba. To ne znači da je mogućnost progresije veća kod ispitanika s manjim brojem zuba, što je i u suprotnosti s nalazima u drugim istraživanjima. $U$ našem uzorku prvi stalni molari $s$ demarkiranim opacitetima praćeni su godinu dana kod ispitanika s posteruptivnim puknućem cakline ili netipičnim ispunom na preostala tri ili dva prva stalna molara. Dodatno promatrani incizivi s demarkiranim opacitetima imali su kod ispitanika s tri ili četiri zahvaćena stalna molara različite stupnjeve progresije.

Lokacija demarkiranog opaciteta nije analizirana u regresijskom modelu zbog činjenice da progresija nije zabilježena ni na jednom zubu na kojemu je demarkirani opacitet bio na glatkim površinama. Samo nepostojanje takva zuba upućuje 
stage on index teeth. Age of 8 years was recommended as optimal one for MIH examination (26). There are studies that included younger population but with goal to achieve a necessary sample size in cross sectional study (27). But, in populations with medium and high caries rate in primary dentition, such as the one studied in this research, registration should be performed even earlier. Thus, in such populations, monitoring of first permanent molars should be performed even during eruption.

The presence of Hypomineralised Second Primary Molars (HSPM) is also frequently investigated and considered as a predictive factor for MIH $(13,26)$. A new MIH/HSPM index was introduced recently in order to grade the clinical status, amount of tooth surface area affected, and other enamel defects comparable to MIH presence (13). Atypical caries was added as criterion of clinical status registration and lesion extension criteria was also registered ( 3 stages: less than one-third of the tooth affected; at least one-third but less than two-thirds of the tooth affected; at least two-thirds of the tooth affected) (13). The registration of location of demarcated opacities was not included in this index.

After conduction of our research a new index, the MIH Treatment Need Index (MIH-TNI) was introduced. It was designed to assess and plan treatment needs, providing information about the severity of MIH in populations and individuals. The index is based on essential parameters of demarcated opacity and symptoms which are clinically considered to be the most important ones with respect to MIH: hypersensitivity and PEB (28). A significant hypersensitivity of $\mathrm{MIH}$ teeth can cause discomfort and pain during oral hygiene performance. Additionally, it can affect eating habits $(9,10)$. Dental fear and behavior management problems in children with severe enamel hypomineralisation are also reported (29). In previous studies of MIH conducted in Bosnia and Herzegovina, no hypersensitivity of teeth affected was reported $(16,30)$. In a recent study, which was conducted to test different protocols for reducing sensitivity of hypomineralised teeth, the tactile and an air blast examination was used to register hypersensitivity score (31). If the presence of sensitivity is to be routinely registered in MIH studies, a clear methodology of such registration should be agreed.

\section{Conclusions}

Monitoring of first permanent molars during eruption is needed in populations with medium and high rates of caries in their primary dentition. Screenings for MIH in our population should be performed at age 5-6, along with a subsequent examination of Second Primary Molars. Dark color and localization of demarcated opacity should be determined as significant factors, which could have an impact in predicting demarcated opacity progression within molar incisor hypomineralisation. Further research into the occurrence of demarcated opacities and their role in predicting disease progress is recommended. na značenje ispitivanja lokacije DO-a, što je donekle objašnjeno visokom korelacijom progresije bolesti i okluzalno-incizalne lokacije demarkiranog opaciteta na zubu.

Veličina zubne površine zahvaćene demarkiranim opacitetom (u postotcima) nije uvrštena u predikcijski model, što može biti u vezi s malim brojem opserviranih zuba.

Ograničenost naše studije u dobi promatrane populacije (od 6 do 9 godina) nije omogućila registriranje inicijalnog izgleda indeksnih zuba. Preporučena optimalna dob ispitanika za MIH jest 8 godina (26). Dostupna su i istraživanja u koja su bili uključeni i mlađi ispitanici sa svrhom dobivanja potrebne veličine uzorka u presječnom ispitivanju (27)

U populacijama sa srednjim i visokim karijesnim rizikom ispitivanje $\mathrm{MIH}-\mathrm{a}$ treba obavljati neposredno poslije erupcije prvih stalnih molara i inciziva.

Hipomineralizacija drugih mliječnih molara dosta je istraživana $\mathrm{i}$ smatra se predikcijskim čimbenikom $\mathrm{MIH}$-a $(13,26)$. MIH/HSPM indeksom koji je nedavno uveden želi se obuhvatiti gradacija kliničkoga statusa i stupanj zahvaćenosti zubne površine hipomineralizacijom te drugi caklinski defekti slični MIH-u (13). Dodana je i nova kategorija - netipični karijes te je predložena registracija veličine defekta (tri kategorije zahvaćenosti površine: manje od jedne trećine; više od jedne trećine, a manje od dvije trećine; minimalno dvije trećine zuba) (13). U navedenom indeksu ne razmatra se lokalizacija demarkiranog opaciteta.

MIH indeks je novijega datuma, predložen nakon što je završeno naše istraživanje. Osmišljen je sa svrhom utvrđivanja i planiranja tretmana, a usto pruža informacije o ozbiljnosti MIH-a u populaciji i kod pojedinaca. Temelji se na osnovnim parametrima demarkiranih opaciteta i klinički važnim simptomima - hipersenzitivnosti i PLC-u (28). Pojačana osjetljivost zuba u sklopu MIH-a može prouzročiti neugodu i bolnost pri obavljanju oralne higijene, a dodatno može utjecati na prehranu $(9,10)$. Dentalni strah i problemi u ponašanju djece $s$ težim oblicima hipomineralizacije su dokumentirani (29). U dostupnim istraživanjima o MIH-u u Bosni i Hercegovini kod naših ispitanika nije zabilježena hipersenzitivnost $(16,30)$. Dostupne su studije u kojima se ispituju protokoli za reduciranje hipersenzitivnosti hipomineraliziranih zuba, a sam stupanj preosjetljivosti ispituje se taktilno i zračnim podražajem (31). Ako se u daljnjim istraživanjima potvrdi potreba za registriranjem stupnja osjetljivosti zuba s hipomineralizacijama, potrebno je definirati jasnu metodologiju.

\section{Zaključci}

U sklopu ispitivanja MIH-a, a u populacijama sa srednjim i visokim karijesnim rizikom, praćenje prvih stalnih molara treba obavljati neposredno poslije erupcije. Pregledi u našoj populaciji preporučuju za dob od 5 do 6 godina, uz obvezno praćenje ostalih mliječnih molara.

Tamna boja i lokalizacija demarkiranog opaciteta važni su čimbenici koji imaju ulogu u predikciji progresije demarkiranog opaciteta u sklopu molarno-incizivnih hipomineralizacija.

Preporučuju se daljnja istraživanja predikcije progresije bolesti na osnovi parametara DO-a. 


\section{Conflict of interest}

None declared

\section{Compliance with ethical standards}

Ethical approval: Research is conducted in accordance with the ethical standards and 1964 Helsinki declaration and was approved by Faculty of Dentistry, University of Sarajevo (Scientific and Educational Committee, 09-263-1/2010).

Informed consent: The informed consent was obtained from children's parents.

\section{Author`s contributions}

A.A. - Conception and design; A.A., N.M. and L.B.R. Acquisition, analysis and interpretation; A.A., E.B. - Drafting the article; A.A., N.M., E.B. - Revising it critically for important intellectual content; A.A., N.M., E.B., L.B.R. Approved final version of the manuscript.

\section{Sukob interesa}

Autor nisu bili u sukobu interesa.

\section{Etički standard}

Istraživanje je provedeno u skladu sa etičkim standardima i Helsinškom deklaracijom, odobreno od Stomatološkog fakulteta, Sveučilišta u Sarajevu (nastavno znanstveno vijeće 09-263-1/2010).

Informirani pristanak: Informirani pristanci su dobiveni od roditelja ispitanika.

\section{Doprinos autora}

A. A. - koncept i dizajn; A. A, N. M. i L. B. R. - prikupljanje, analiza i interpretacija podataka; A. A., E. B. - nacrt rukopisa; A. A., N. M. i E. B. - ključne preinake u dopuni intelektualnog sadržaja; A. A., N. M., E. B. i L. B. R. - odobravanje završne verzije rukopisa.

\section{Sažetak}

Svrha rada: Opservirani su demarkirani opaciteti (DO) na zubima zahvaćenima molarno-incizivnim hipomineralizacijama $(\mathrm{MIH})$ sa svrhom ispitivanja povezanosti izgleda DO-a te broja zahvaćenih zuba s predikcijom progresije bolesti. Materijal i metode: Na uzorku od 446 sarajevskih ispitanika pregledanih 2009. godine (dob 6 do 9 godina), utvrdena je prevalencija $\mathrm{MIH}-\mathrm{a}$ od $11,5 \%$, $(n=51)$. Istraživanjem su bili obuhvaćeni ispitanici s potvrđenom dijagnozom MIH-a čiji su se roditelji složili sa sudjelovanjem u jednogodišnjoj studiji $(n=25)$. Rezultati: U uzorak je bilo uključeno 29 stalnih inciziva i 14 prvih stalnih molara na kojima su uočeni DO-i. Broj zuba sa svijetlim demarkiranim opacitetima bio je znatno veći negoli s tamnima. Brojniji su bili demarkirani opaciteti locirani na glatkim plohama koje nisu izložene silama tijekom žvakanja. U postotku se zahvaćenost zubnih površina demarkiranih opacitetom kretala se od 1,33 \% do 56,56\%. Broj zahvaćenih zuba iznosio je od 2 do 6 . Uočena je pozitivna korelacija između progresije bolesti i tamnih opaciteta na okluzalnim/incizalnim površinama zuba. Tamnij opaciteti zahvaćali su veće površine zuba. DO na incizivima češće je lociran na vestibularnim površinama, a na prvim stalnim molarima okluzalno. Zaključci: Tamnija boja DO-a pokazala se najboljim pojedinačnim pokazateljem progresije bolesti te tamnija boja u kombinaciji s brojem zahvaćenih zuba. Kao dobar nezavisni prediktor progresije $\mathrm{MIH}$-a pokazala se lokalizacija demarkiranog opaciteta. Zato je važno zabilježiti podatke o boji i lokalizaciji DO-a.
Zaprimljen: 17. travnja 2020. Prihvaćen: 22. listopada 2020.

Adresa za dopisivanje

Amra Arslanagić

Sveučilište u Sarajevu

Stomatološki fakultet s klinikama

Katedra za dječju i preventivnu stomatologiju

Bolnička 4 a, 71000 Sarajevo, Bosna i Hercegovina aarslanagic@sf.unsa.ba

Ključne riječi molarno-incizivna hipomineralizacija HIP; hipoplazija zubne cakline; promjena boje zuba; napredovanje bolesti

\section{References}

1. Fayle SA. Molar Incisor Hypomineralisations: restorative menagement. Eur J Peadiatr Dent. 2003;4(3): 121-125.

2. William V, Messer LB, Burrow MF. Molar incisor hypomineralization: review and recommendations for clinical management. Pediatr Dent. May-Jun 2006;28(3):224-32.

3. Mathu-Muju K, Wright JT. Diagnosis and treatment of molar incisor hypomineralization. Compend Contin Educ Dent. 2006 Nov;27(11):604-10; quiz 611.

4. Fitzpatrik L, O’Connell A. First permanent molars with molar incisor hypomineralization. J Ir Dent Assoc. Spring 2007;53(1):32-7.

5. Willmott NS, Bryan RAE, Duggal MS. Molar-Incisor-Hypomineralization: A literature review. Eur Arch Paediatr Dent. 2008;9:172179.

6. Koch G, Hallonsten AL, Ludvigsson N, Hansson BO, Holst A, Ullbro C. Epidemiologic study of idiopathic enamel Hypomineralizations in permanent teeth of Swedish children. Community Dent Oral Epidemiol. 1987;15(5):279-85

7. Balmer RC, Laskey D, Mahoney E, Toumba KJ. Prevalence of enamel defects and MIH in non-fluoridated and fluoridated communities. Eur J Paediatric Dent. 2005;5:209-212.

8. Neves AB, Americano GCA, Soares DV, Soviero VM. Breakdown of demarcated opacities related to molar-incisor hypomineralization: a longitudinal study. Clin Oral Invest. 2018; 23:611-615.

9. Jalevik B. Enamel hypomineralisations in permanent first molars. A clinical, histo-morphological and biochemical study. Swed Dent J Suppl. 2001;(149):1-86

10. Weerheijm KL, Duggal M, Mejare I, Papagiannoulis L, Koch G, Martens LC, Hallonsten AL. Judgement criteria for Molar Incisor
Hypomineralisations $(\mathrm{MIH})$ in epidemiological studies: a summary of the European meeting on MIH held in Athens, 2003. Eur J Peadiatr Dent. 2003;4(3):110-113.

11. Lygidakis NA, Dimou G, Briseniou E. Molar incisor hypomineralization (MIH). Retrospective clinical study in Greek children. I. Prevalence and defect characteristics. Eur Arch Paediatr Dent. 2008 Dec;9(4):200-6.

12. Lygidakis NA, Dimou G, Briseniou E. Molar incisor hypomineralisation (MIH). Retrospective clinical study in Greek children. II. Possible medical aetiological factors. Eur Arch Paediatr Dent. 2008 Dec;9(4):207-17.

13. Ghanim A, Mariño R, Manton DJ. Validity and reproducibility testing of the Molar Incisor Hypomineralisation (MIH) Index. Int J Paediatr Dent. 2018; 00:1-8.

14. Leppaniemi A, Lukinmaa PL, Alaluusua S. Nonfluoride hypomineralisations in the permanent first molars and their impact on the treatment need. Caries Res. Jan-Feb 2001;35(1):36-40.

15. Dietrich G, Sperling S, Hetzer G. Molar Incisor Hypomineralisation in a group of children and adolescents living in Dresden (Germany). Eur J Peadiatr Dent. 2003;4(3):133-137.

16. Muratbegović A, Marković N, Ganibegović Selimović M. Molar incisor hypomineralisation in Bosnia and Herzegovina: aetiology and clinical consequences in medium caries activity population. Eur Arch Paediatr Dent. 2007 Dec;8(4):189-94.

17. Williams R, Vidal A. Perez VA, Mangum JE, Hubbard MJ. Pathogenesis of Molar Hypomineralisation: Hypomineralised 6-Year Molars Contain Traces of Fetal Serum Albumin. Front Physiol. 2020 Jun 12;11:619. 
18. Farah R, Drummond B, Swain M, Williams S. Linking the clinical presentation of molar-incisor hypomineralisation to its mineral density. Int J Paediatr Dent. 2010; 20: 353-360.

19. Alaluusua S, Lukinamaa PL, Koskimies M, Pirinen S, Holtta P, Kallio $M$, et al. Development dental defects associated with long breast feeding. Eur J Oral Sci. 1996; 104: 493-497.

20. Calderara PC, Gerthoux PM, Mocarelli P, Lukinmaa PL, Tramacere PL, Alaluusua S. The prevalence of Molar Incisor Hypomineralisation $(\mathrm{MIH})$ in a group of Italian school children. Eur J Paediatr Dent. 2005;6(2):79-83.

21. Lygidakis NA, Wong F, Jalevik B, Vierrou A-M, Alaluusua S, Espelid I. Best clinical practice Guidance for clinicians dealing with children presenting with molar- incisor -hypomineralisation $(\mathrm{MIH})$. An EAPD Policy document. Eur J Paediatr Dent. 2010;11(2):75-81.

22. Jalevik B, Klinberg G, Barregard L, Noren JG. The prevalence of demarcated opacities in permanent first molars in a group of Swedish children. Acta Odontol Scand. 2001 Oct;59(5):255-60.

23. Jasulaityte L, Veerkamp JS, Weerheijm KL. Molar incisor hipomineralization: review and prevalence data from the study of primary school children in Kaunas/Lithuania. Eur Arch Paediatr Dent. 2007; 8(2):87-84.

24. Weerheijm KL, Groen HJ, Beentjes VE, Poorterman JH. Prevalence of cheese molars in eleven-year-old Dutch children. ASDC J Dent Child. 2001;68(4): 259-62.

25. Preusser SE, Ferring V, Wleklinski C, Wetzele E. Prevalence and severity of Molar-Incisor-Hypomineralisation in a region of Ger-
many-A brief communication. J Public Health Dent. Summer 2007;67(3):148-50.

26. Elfrink MEC, Ghanim A, Manton DJ, Weerheijm KL. Standardised studies on Molar Incisor Hypomineralisation $(\mathrm{MIH})$ an d Hypomineralised Second Primary Molars (HSPM): a need. Eur Arch Paediatr Dent. 2015; 16:247-255.

27. Hernández M, Boj JR, Espasa E, Peretz B. First Permanent Molars and Permanent Incisors Teeth by Tooth Prevalence of Molar-Incisor-Hypomineralisation in a Group of Spanish Schoolchildren. Acta Stomatol Croat. 2018 Mar;52(1):4-11.

28. Steffen R, Krämer N, Bekes K. The Wurzburg MIH concept: the $\mathrm{MIH}$ treatment need index (MIH TNI). A new index to assess and plan treatment in patients with molar incisior hypomineralisation (MIH). Eur Arch Paediatr Dent. 2017; 18:355-361.

29. Jalevik B, Klinberg G. Dental treatment, dental fear and behavior management problems in children with severe enamel hypomineralisation in their permanent first molars. Int J Paediatr Dent. 2002;12:24-32.

30. Mulic E, Cehajic A, Tveit AB, Stenhagen KR. How serious is Molar Incisor Hypomineralisation (MIH) among 8- and 9-year - old children in Bosnia- Herzegovina? A clinical study. Eur J Paediatr Dent. 2017 Jun;18(2):153-157.

31. Bekes K, Heinzelmann K, Lettner S, Schaller HG. Efficacy of desensitizing products containing $8 \%$ arginine and calcium carbonate for hypersensitivity relief in MIH-affected molars: an 8-week clinical study. Clin Oral Invest. 2017; 21:2311-2317. 